University of Nebraska - Lincoln

DigitalCommons@University of Nebraska - Lincoln

Educational Psychology Papers and

Publications

Educational Psychology, Department of

November 2002

\title{
Homophobia and Academic Freedom
}

David Moshman

University of Nebraska-Lincoln, dmoshman1@unl.edu

Follow this and additional works at: https://digitalcommons.unl.edu/edpsychpapers

Part of the Educational Psychology Commons

Moshman, David, "Homophobia and Academic Freedom" (2002). Educational Psychology Papers and Publications. 39.

https://digitalcommons.unl.edu/edpsychpapers/39

This Article is brought to you for free and open access by the Educational Psychology, Department of at DigitalCommons@University of Nebraska - Lincoln. It has been accepted for inclusion in Educational Psychology Papers and Publications by an authorized administrator of DigitalCommons@University of Nebraska - Lincoln. 


\title{
Homophobia and Academic Freedom
}

\author{
David Moshman
}

SUMMARY. Addressing homophobia and heterosexism as a teacher raises issues of respect for the intellectual freedom of your students. The central thesis of this article is that these issues are best addressed on the basis of general principles of academic freedom-that is, intellectual freedom in educational and research contexts. Three cases are analyzed on the basis of principles developed by the Academic Freedom Coalition of Nebraska (AFCON). These principles permit advocacy, rather than requiring neutrality, but do not permit indoctrination. That is, instructors may express and justify their own ideas relevant to the curriculum and try to convince students to adopt those ideas and/or abandon alternatives, but must not coerce or require belief, censor or punish students who remain unconvinced, or restrict access to alternative views. [Article copies available for a fee from The Haworth Document Delivery Service: 1-800-HAWORTH. E-mail address: <getinfo@ haworthpressinc.com> Website: <http://www.HaworthPress.com> (c) 2002 by The Haworth Press, Inc. All rights reserved.]

KEYWORDS. Homophobia, academic freedom, intellectual freedom, censorship, indoctrination

David Moshman, PhD, is Professor of Educational Psychology at the University of Nebraska-Lincoln, and Policy Coordinator of the Academic Freedom Coalition of Nebraska.

[Haworth co-indexing entry note]: "Homophobia and Academic Freedom." Moshman, David. Co-published simultaneously in Journal of Lesbian Studies (Harrington Park Press, an imprint of The Haworth Press, Inc.) Vol. 6, No. 3/4, 2002, pp. 147-161; and: Addressing Homophobia and Heterosexism on College Campuses (ed: Elizabeth P. Cramer) Harrington Park Press, an imprint of The Haworth Press, Inc., 2002, pp. 147-161. Single or multiple copies of this article are available for a fee from The Haworth Document Delivery Service [1-800-HAWORTH, 9:00 a.m. - 5:00 p.m. (EST). E-mail address: getinfo $@$ haworthpressinc.com].

(c) 2002 by The Haworth Press, Inc. All rights reserved. 
Addressing homophobia and heterosexism as a teacher immediately raises issues of respect for the intellectual freedom of your students. How free should you be to raise issues of sexual orientation in your classes? How free should you be to express and argue for your own views on these issues? How free should students be to express views that you deem homophobic or heterosexist?

The central thesis of this article is that issues of this sort are best addressed on the basis of principles of academic freedom. By academic freedom, I mean intellectual freedom in educational and research contexts, the definition used by the Academic Freedom Coalition of Nebraska (AFCON) since its founding in 1988. Thus academic freedom fully encompasses students and faculty at all levels of education. Some aspects of academic freedom may be legally protected in some contexts, but academic freedom is not a set of legal rights. Rather, it is a social context of liberty justified by the role of intellectual freedom in education and by the various moral and professional rights and responsibilities associated with this.

On the basis of this conception AFCON has developed a set of Principles of Academic Freedom (see appendix a) and a subsequent Statement applying these principles to matters of sexuality. In the next section I briefly describe the history leading to the adoption of these documents. The rest of the article illustrates the application of academic freedom principles to three cases.

\section{PRINCIPLES OF ACADEMIC FREEDOM}

AFCON was founded in 1988 as a coalition of Nebraska organizations concerned with intellectual freedom in the educational institutions of Nebraska. Current members of the coalition include the Nebraska State Education Association, the Lincoln Education Association, the Nebraska Educational Media Association, the Lincoln Public School Media, the Nebraska English/Language Arts Council, the Nebraska High School Press Association, the Nebraska State Reading Association, the University of Nebraska--Lincoln (UNL) Academic Senate, the UNL Chapter of the American Association of University Professors, the Nebraska Chapter of the National Association of Scholars, ACLU Nebraska, the Nebraska Library Association, the Nebraska Press Association, the Nebraska Center for the Book, Journal Writers of Nebraska, the Story Monkey, and the Nebraska Writers Guild. Members of the coalition select representatives to serve on the AFCON Board of Directors.

Since its beginning AFCON has construed academic freedom as intellectual freedom in educational and research contexts. Such freedom can sometimes be protected in U.S. public education by invoking the First Amendment rights of individual students or faculty (Kors \& Silverglate, 1999; O'Neil,
1997). AFCON has consistently maintained, however, along with the American Association of University Professors (1940/2001), that academic freedom is fundamentally a condition for education and research, not just a set of legal rights. That is, adherence to principles of academic freedom fosters excellence in education and research while simultaneously respecting the autonomy of individual students and faculty. This emphasis on the intellectual and moral, as opposed to legal, basis for academic freedom has become increasingly important since Hazelwood v. Kuhlmeier (1988), in which the U.S. Supreme Court greatly restricted the application of the First Amendment in curricular contexts.

Throughout its history, many of the cases coming to AFCON's attention have involved issues of sexual orientation. Given that this experience was fully consistent with national trends and showed no sign of abating, the AFCON Board decided in 1998 to develop a policy statement concerning issues of academic freedom related to sexual orientation. Although drafts of such a policy received positive feedback from a variety of sources, an unexpected problem arose. Some people thought it odd that AFCON was singling out sexual orientation for special attention and wondered whether the policy was providing special protection for the topic of sexual orientation and/or special rights for sexual minority faculty and/or students.

Within AFCON it was obvious to everyone that there was no question of special protections or special rights. The principles central to the draft policy were the principles AFCON had consistently applied throughout its history in addressing all sorts of academic freedom issues and controversies. We realized, however, that our most fundamental principles had for the most part been implicit in our analyses and positions rather than explicit objects of systematic attention. Outside our organizational context, our proposed policy on sexual orientation did indeed seem to be creating special protections and rights for certain topics and persons.

With these considerations in mind we decided that, rather than approve a special document concerning sexual orientation, it would be better to step back, formulate and approve an explicit version of our general principles of academic freedom, and then return to the topic of sexual orientation as part of a more general treatment of sexuality that was itself based directly on AFCON's general principles. The result of this process was a set of Principles of Academic Freedom adopted by the AFCON Board in September 1999 (see appendix a) and a longer statement entitled "Sexuality and Academic Freedom," based on these principles, that was approved by the AFCON Board in April 2000 (available at http://www.NebrWesleyan.edu/offices/library/Afcon).

AFCON's statement on sexuality begins by noting AFCON's concern that "the dozens of cases involving human sexuality that AFCON has addressed in recent years are just the tip of the iceberg that chills education about sexuality throughout 
Nebraska" (p. 1). Far from receiving special protection, the topic of sexuality is routinely treated as one requiring especially stringent restrictions on expression:

Implicit in most efforts to restrict discussion of sexuality is a widely-shared assumption that human sexuality is special in ways that render standard principles of academic freedom irrelevant. We see no justification for this view. In this statement we apply general principles of academic freedom to seven overlapping areas of concern with regard to sexuality and academic freedom. (p. 1)

The statement then goes on the address (a) sexuality within the curriculum, (b) teaching sexual responsibility, (c) student freedom of belief and expression, (d) freedom of inquiry, (e) sexual harassment, (f) equal opportunity, and (g) sexual orientation. With regard to the latter it notes that

[s]everal of the examples used in this policy statement involve sexual orientation. This reflects the reality that a large proportion of the complaints and concerns that come to our attention involve sexual orientation. The fact that issues of sexual orientation are controversial in our society does not justify censorship. On the contrary, recognizing that the urge to restrict intellectual freedom is always strongest with regard to controversial matters, school authorities should be especially vigilant in protecting intellectual freedom with regard to matters of sexual orientation. (p. 3)

In the remainder of this article, I analyze three illustrative cases involving matters of sexual orientation. The first, involving the use of an epithet to express an offensive point of view, is hypothetical. The second, involving an offended Christian, is adapted from my own experiences teaching about the development of sexual orientation and sexual identity in a course on adolescent psychology. The third, in which a graduate assistant teaches about alleged cures for homosexuality, is an actual case that arose in the counseling psychology program of my department. Beyond whatever specific insights these analyses may yield, I hope to demonstrate that AFCON's general principles of academic freedom provide a useful framework for generating consistent and justifiable responses to educational issues and circumstances concerning matters of sexual orientation.

\section{CASE STUDIES}

Case One. In a class discussion of what is encompassed in the concept of fundamental rights, a student argues that fundamental rights include the right not to be discriminated against because of your sexual orientation. Another student says this sort of absurd claim shows the problem with vague notions of human rights. A third student agrees with the second, noting how vagueness leads to overly broad conceptions of rights that protect immoral behavior and evil people. A fourth student adds that human rights can't protect everyone and everything. The first student replies that human rights, by definition, are rights that protect all people. "Yeah, people," murmurs a fifth student, "not faggots." You're the teacher.

It is readily understandable that a teacher in this situation might feel increasingly disappointed and frustrated by the successive comments of the second, third, and fourth students. Even if you recognize the right of these three students to express their views you may be tempted, especially given this context, to penalize the fifth student for using the term "faggot" or at least to warn students that they will be punished for using that word. This temptation, I will argue, should be resisted, not only out of respect for the rights of your students but also because, from an educational point of view, there are better ways to handle this situation.

A central theme of AFCON's Principles is that academic freedom applies not only to faculty but to students as well. Your students, no less than you, have "a right to believe whatever they believe" (Principle 2) and "a right to express their views" (Principle 3). These principles can be justified on both moral and educational grounds. Morally, respect for persons entails respect for their intellectual autonomy, even if you justifiably believe them to be less developed and/or less educated than yourself (Kors \& Silverglate, 1999). Educationally, moreover, there is substantial evidence that learning and development are fostered by contexts of intellectual freedom (Moshman, 1998, 1999).

It might be argued that freedom of expression is not absolute and that this is one of those cases where common sense demands some limitation. It is indeed true that restrictions on the time, place, or manner of expression can sometimes be justified, but we should be wary of relying on "common sense" to guide us in this regard. Rather, we should be careful that any such restrictions are carefully delineated and justified, and that they are neutral with regard to viewpoint.

In academic contexts, in particular, freedom of expression may justifiably be limited to matters "relevant to the curriculum" (Principle 3). A student who persistently talks about "faggots" in a calculus class, for example, might justifiably be required to stick to the topic of calculus and ultimately penalized for failing to do so. A student who persistently interrupts a calculus class to endorse gay rights, however, should be equally subject to sanction. Viewpoint neutrality is key here. Legitimate limitations on classroom speech, moreover, should not be abused by applying a stricter standard of relevance to objection- 
able views. The fifth student in the present case may be expressing a highly objectionable view of gays and lesbians, and may be expressing it in a rather inarticulate way (a point to which I shall return), but the student is indeed expressing a view relevant to the topic under discussion.

It might be argued that what distinguishes the fifth student from the second, third, and fourth is not viewpoint but rather the use of the epithet "faggot." Perhaps we cannot punish students for opposing gay rights but can't we punish students who use terms so offensive to others in the class that their manner of expression, as distinct from their point of view, is an act of harassment? Otherwise, some students may be so offended as to be silenced, thus denying them an equal opportunity to exercise their own academic freedom (Principle 8).

There is something to be said for this argument, but there is also great danger in it. As we will see in Case Two, it is not only sexual minorities who may be offended by their fellow students. The key to addressing this issue in a fair and consistent way, I think, is to carefully distinguish offensive speech from acts of harassment. Academic freedom protects the expression of all viewpoints, "even if those views are deemed to be false, absurd, offensive, or otherwise objectionable" (Principle 3). As noted in the Sexuality statement, however, academic freedom does not protect harassment, strictly defined as "a pattern of actions specifically directed against a particular individual with the intent of humiliating, intimidating, or otherwise harming that individual" (p. 2). If a student were to repeatedly call someone else in the class a faggot (or a bitch, kike, etc.) despite clear indication that the other student found this objectionable, that would be a serious offense not protected by norms of academic freedom. Reasonable people might disagree on exactly where one draws the line between offensive speech and harassment, but it should be clear that the comment of the fifth student in the present case falls far short of that line.

What, then, should you do in the present case? One important option for a teacher in any case involving student discussion is not to say anything at all. Peer interaction has a dynamic of its own that can be highly effective in promoting development and education and that may be undermined by pronouncements from a teacher or other authority (Moshman, 1998, 1999). It is possible in the present case that if you hold your tongue for a moment, other students, perhaps even including those opposed to gay rights, will criticize the use of the term "faggot" and, precisely because they are peers, have more impact than you could possibly have had.

There is no guarantee that this will happen, however. It is possible that there will be a stunned silence as students wait to see your reaction and that if you do not react this will be taken as acquiescence. It is also possible that if you do not step in, the discussion will move on to something else and your opportunity to use the present situation for educational purposes will be lost. Your own aca- demic freedom as the teacher to decide how to proceed is based on the assumption that you are in the best position to judge what will be most educational for your students.

One excellent option, I suggest, is to ask the fifth student to clarify and justify his or her view. More specifically, you might, with seeming innocence, ask what is meant by "faggot" and why individuals in this category do not qualify as people. This response is, to be sure, a bit disingenuous. You are not directly accusing the student of making a snide and ignorant remark that fails to advance the discussion but you have no objection if the student or others make this inference. The student may be unpleasantly surprised to be asked to justify a comment that was not meant to be taken seriously, at least not in any academic sense. If the student has no meaningful response to your query, others in the class may conclude that comments of this sort are unjustifiable and some may go on to question the earlier facile rejections of gay rights. They may also come to see that intellectual discussions are more than just serial statements of diverse opinions. They may see that in your classroom they are free to say whatever they wish but that they should be prepared to explain and justify whatever they say.

It is possible, of course, that the student will indeed have some response. You can then proceed from there to state your own views about the use of terms like "faggot" and/or about the nature and scope of fundamental human rights. Respect for a student's right to hold a particular opinion does not entail agreement with, or even respect for, that opinion. On the contrary, respect for students is fully consistent with the presentation of alternative views and with efforts to convince students to change their opinions. The key is that such efforts must not be, and must not be perceived to be, coercive. It should be clear both to you and your students that, in the end, they "have a right to believe whatever they believe and to maintain or change their beliefs as they deem appropriate" (Principle 2).

Case Two. A class is discussing the psychological impact of discrimination on various groups. A student says that the major problem for gays is the psychological impact of Christian biases and bigotry. Another student says these remarks offend him as a Christian. Other students agree with the first that Christians are indeed, for the most part, homophobic bigots whose hateful rhetoric causes ongoing violence against gays and lesbians. The Christian student gets up to leave. What should you do as the teacher?

Two seemingly contradictory points are key in addressing this issue. First, the student has a right to leave. And second, you should try to convince him to stay.

With regard to the first point, you do have general authority as the teacher to set reasonable standards, including standards of class attendance, for passing, or receiving high grades in, your course. You have no obligation to devise cri- 
teria that will enable a student who finds your course offensive to receive an A without ever attending class. Students sometimes do have good reasons for missing class, however, and all teachers should make provisions for accommodating at least a few justified absences. In the present case, the student may be angry and upset about what he perceives as a personal attack and/or an assault on his religious beliefs. He may have learned from past experience that it is important for him to get away and cool down when he feels too angry to maintain his composure. You do not have to excuse him from whatever work he misses, but you should not forbid him to leave.

Even as you acknowledge his right to leave, however, you can and should try to convince him to stay, even if you believe that he is indeed a homophobic bigot and that his departure would help the class achieve a consensus consistent with your own views. There are at least three reasons for this. First, the departure of any student will obviously limit the education of that student. Your obligations to your students are not limited to those students who share your beliefs (Principle 8). Second, if your specific intent is to educate students about sexual orientation and alleviate homophobia, homophobic students are precisely the audience you most need to reach. The departure of an apparently homophobic student, and the consequent alienation of other Christian and/or homophobic students, thus undermines the achievement of your pedagogical goals. Finally, given that the Christian student appears to represent a minority view in this class, his departure will decrease the diversity of views in your classroom. If other students perceive it as best not to share what they see as a disfavored view, moreover, the opportunity for productive discussion is greatly compromised.

What will it take to convince the Christian student to stay? Quite possibly, he might like to see you show your support for him personally and/or for civil discussion in your classroom by punishing those who have called him a homophobic bigot.

On a continuum from offensiveness to harassment, the present circumstances arguably fall a bit closer to harassment than those of Case One. As offensive as the term "faggot" may be, no particular person was called a faggot in Case One, whereas the Christian student in the present case heard Christians denounced as homophobic bigots immediately after he identified himself as a Christian. He might believe the statements he found so offensive were aimed at him in particular with the intent to humiliate and silence him.

On the present facts, however, you have no reason to doubt that the students who said most Christians are homophobic bigots genuinely believe this, and you must be clear with all your students that they have a right to hold and express this view. Even if students were to say that all Christians are homophobic bigots, an assertion that is demonstrably false, you must be clear that students have a right to believe this and a right to say what they believe. If some of your students follow the Christian student back to his dorm room and continue to berate him for his views after he has made it clear that he no longer wishes to discuss the issue, they may be guilty of harassment. Wherever the line separating offensiveness from harassment may be, however, it clearly is not reached in the present case.

Unless the present case is part of a larger picture of targeted abuse, then, there is no question of harassment. Without singling anyone out for punishment, however, there is much you can do to simultaneously support the offended student, support the students who have offended him, and turn the present situation to educational advantage. For a start, you can assure the Christian student as he heads for the door that you understand why he is upset, that you intend to seriously address what has just happened in the class, and that you believe his presence will enhance the discussion to follow. You should be clear that you are not telling him to stay but asking him to stay, and that you are requesting this not just because he has a right to be in the class but because you believe his potential contributions will enhance the educational value of the class.

How you proceed from this point will depend not only on whether the Christian student decides to stay but also on what you know of the class and on how your students react to the situation. At the very least, however, you have an opportunity to encourage your students to avoid stereotyping, to express themselves in a civil manner, and to respect and value ideological diversity. You can and should promote these dispositions and values without censorship or punishment. In the short run, the most efficient way to ensure civil discussions in which no one is offended may be to set strict rules students must follow to avoid penalties. The resulting discussions, however, are likely to be not only civil but bland. In the long run, you want students to engage in civil and productive discussions out of respect for each other rather than due to fear of your power to censor and punish.

It is quite possible, I should add, that in a case of this sort the offended student might be out the door before you have time to decide what to do and gone before you can go after him. You should not berate yourself for failing to devise Solomonic responses to difficult circumstances in the blink of an eye. Even if the offended student is gone, however, the considerations raised above can direct you in discussing what just happened with the remaining students in the class, letting them know that you hope to restore relations with the offended student, explaining why, and inviting them to assist you. Following through with the offended student may not only be the right thing to do for his sake but may also provide the rest of the class with a useful model of maintaining dialogue and community in the face of deep disagreements. 
teria that will enable a student who finds your course offensive to receive an A without ever attending class. Students sometimes do have good reasons for missing class, however, and all teachers should make provisions for accommodating at least a few justified absences. In the present case, the student may be angry and upset about what he perceives as a personal attack and/or an assault on his religious beliefs. He may have learned from past experience that it is important for him to get away and cool down when he feels too angry to maintain his composure. You do not have to excuse him from whatever work he misses, but you should not forbid him to leave.

Even as you acknowledge his right to leave, however, you can and should try to convince him to stay, even if you believe that he is indeed a homophobic bigot and that his departure would help the class achieve a consensus consistent with your own views. There are at least three reasons for this. First, the departure of any student will obviously limit the education of that student. Your obligations to your students are not limited to those students who share your beliefs (Principle 8). Second, if your specific intent is to educate students about sexual orientation and alleviate homophobia, homophobic students are precisely the audience you most need to reach. The departure of an apparently homophobic student, and the consequent alienation of other Christian and/or homophobic students, thus undermines the achievement of your pedagogical goals. Finally, given that the Christian student appears to represent a minority view in this class, his departure will decrease the diversity of views in your classroom. If other students perceive it as best not to share what they see as a disfavored view, moreover, the opportunity for productive discussion is greatly compromised.

What will it take to convince the Christian student to stay? Quite possibly, he might like to see you show your support for him personally and/or for civil discussion in your classroom by punishing those who have called him a homophobic bigot.

On a continuum from offensiveness to harassment, the present circumstances arguably fall a bit closer to harassment than those of Case One. As offensive as the term "faggot" may be, no particular person was called a faggot in Case One, whereas the Christian student in the present case heard Christians denounced as homophobic bigots immediately after he identified himself as a Christian. He might believe the statements he found so offensive were aimed at him in particular with the intent to humiliate and silence him.

On the present facts, however, you have no reason to doubt that the students who said most Christians are homophobic bigots genuinely believe this, and you must be clear with all your students that they have a right to hold and express this view. Even if students were to say that all Christians are homophobic bigots, an assertion that is demonstrably false, you must be clear that students have a right to believe this and a right to say what they believe. If some of your students follow the Christian student back to his dorm room and continue to berate him for his views after he has made it clear that he no longer wishes to discuss the issue, they may be guilty of harassment. Wherever the line separating offensiveness from harassment may be, however, it clearly is not reached in the present case.

Unless the present case is part of a larger picture of targeted abuse, then, there is no question of harassment. Without singling anyone out for punishment, however, there is much you can do to simultaneously support the offended student, support the students who have offended him, and turn the present situation to educational advantage. For a start, you can assure the Christian student as he heads for the door that you understand why he is upset, that you intend to seriously address what has just happened in the class, and that you believe his presence will enhance the discussion to follow. You should be clear that you are not telling him to stay but asking him to stay, and that you are requesting this not just because he has a right to be in the class but because you believe his potential contributions will enhance the educational value of the class.

How you proceed from this point will depend not only on whether the Christian student decides to stay but also on what you know of the class and on how your students react to the situation. At the very least, however, you have an opportunity to encourage your students to avoid stereotyping, to express themselves in a civil manner, and to respect and value ideological diversity. You can and should promote these dispositions and values without censorship or punishment. In the short run, the most efficient way to ensure civil discussions in which no one is offended may be to set strict rules students must follow to avoid penalties. The resulting discussions, however, are likely to be not only civil but bland. In the long run, you want students to engage in civil and productive discussions out of respect for each other rather than due to fear of your power to censor and punish.

It is quite possible, I should add, that in a case of this sort the offended student might be out the door before you have time to decide what to do and gone before you can go after him. You should not berate yourself for failing to devise Solomonic responses to difficult circumstances in the blink of an eye. Even if the offended student is gone, however, the considerations raised above can direct you in discussing what just happened with the remaining students in the class, letting them know that you hope to restore relations with the offended student, explaining why, and inviting them to assist you. Following through with the offended student may not only be the right thing to do for his sake but may also provide the rest of the class with a useful model of maintaining dialogue and community in the face of deep disagreements. 
Case Three. A graduate teaching assistant teaches a class of psychology students that homosexuality is a psychosexual disorder than can be reversed through reparative therapies. As the instructor responsible for the course, you think this is false and you know it is contrary to the views of most psychologists and psychological organizations. What should you do? Would it matter if the teacher were a colleague, rather than a graduate student under your supervision?

Cases One and Two both involve students' expression of their own ideas. Teachers also have a right to express their own ideas, but there is nevertheless an important difference between teachers and students. Teachers have a responsibility to organize their classes around an academically defensible curriculum. Correspondingly, those responsible for hiring, supervising, and/or evaluating teachers have the dual responsibility of (a) respecting the academic freedom of individual teachers, and (b) protecting the educational interests and academic freedom of students. The question of what is taught thus raises issues of curriculum that are in some ways more subtle than the question of what an individual has a right to say.

One preliminary consideration in the present case is the nature and scope of the course. If this were a course in calculus, it would be immediately obvious that sexual orientation and psychotherapy are at best tangential, and likely irrelevant, to what students are there to learn. The right of students and teachers to express their views in class is limited to matters "relevant to the curriculum" (Principle 3). Under some circumstances a teacher of calculus might reasonably deem it relevant to note the sexual orientation of a prominent mathematician or to comment on the effectiveness of psychotherapy for math anxiety. For a math teacher to devote substantial class time and attention to issues of sexual orientation and psychotherapy, however, regardless of what viewpoint she or he expresses about these matters, is an abuse of authority. Recognizing that students are a captive audience, teachers must not exploit their position by systematically subjecting their students to personal opinions on matters outside the scope of the course.

These considerations of relevance apply to some extent even in a psychology class. Suppose in the present case that the course for which you are the instructor is a large course in introductory psychology and that the graduate teaching assistants (GTAs) you supervise are responsible for weekly recitation sections intended to assist students in understanding material from the lecture and textbook. Students in this case have a legitimate expectation that their recitation sections will be devoted to the relevant material. GTAs should be free to provide examples and applications that go beyond those provided in lectures and text but they must not simply replace course topics with others that reflect their own idiosyncratic interests and personal agendas. Thus forbidding a GTA to devote an entire session to sexual orientation might be legitimate, providing the ban applies to all GTAs regardless of what point of view they wish to teach about this issue.

To the extent that the topic of sexual orientation is relevant to the course, however, it would infringe on the academic freedom of the GTA to forbid or punish the expression of particular views about this. Students and teachers, including GTAs, "have a right to express their views on any matter relevant to the curriculum even if those views are deemed to be false, absurd, offensive, or otherwise objectionable" (Principle 3)

That's not the end of the analysis, however. As the instructor responsible for the course, you can require that the curriculum include certain content. Thus you can present, or require the GTA to present, whatever information or ideas about sexual orientation and psychotherapy you believe ought to be included in the curriculum. This might include relevant research results, your own interpretations of these results, relevant theories and expert opinions, and/or policies of the American Psychological Association or other organizations.

Note that this approach, consistent with concern for the right of students not to be indoctrinated, instantiates a bias for inclusion, for expanding the curriculum rather than contracting it (Principle 6). You can see to it that students are exposed to whatever information or ideas you deem relevant and appropriate, but you cannot restrict the expression of alternative views by either the GTA or students in the class.

It should be noted that this bias for inclusion is not a requirement that all information and ideas relevant to a topic be included in the curriculum. If you convince the GTA that certain ideas are wrong and should not be presented, she or he is free to delete them, and vice versa (Principle 6, last sentence). It is almost never possible for a curriculum to include all perspectives, hypotheses, arguments, evidence, and interpretations on a given topic and it would thus be absurd to argue that students have a right to a curriculum that encompasses everything. But a GTA should be permitted to go beyond the curriculum you have devised, and students in turn have a right to add additional ideas of their own.

Suppose now that the teacher in question is not a GTA under your supervision but a colleague in your department. Obviously you have no personal authority to require your colleague to teach or not teach anything in particular, nor should your Chair, your Dean, another administrator, or the governing board of the institution have such authority. To the extent that responsibility for a course goes beyond the individual instructor it should be vested in a curriculum committee consisting of faculty and other professionals with relevant expertise. In order to protect the right of students to a curriculum devised on academic rather than political, religious, or other grounds, "[c]urriculum should be determined by teachers and other professionals on the basis of academic considerations" (Principle 5). 
What if there is disagreement between a curriculum committee and an individual teacher? As in the relation of a supervisory instructor and a GTA, the resolution of such disagreement should not consist of vesting ultimate authority at one level or the other. Rather, the structure of authority should reflect a bias toward inclusion rather than exclusion (Principle 6). A curriculum committee might, for example, require that a particular course that serves as a prerequisite for others include particular topics, ideas, and information, but must permit individual teachers the flexibility to add additional topics, ideas, and information relevant to the course.

It is worth adding that colleagues are free to discuss their courses with each other and to recommend and consider modifications. Students and others should also be free to make suggestions. In general, faculty should be more open to "changes that expand the curriculum" than to "changes that contract or restrict it" (Principle 6). With regard to voluntary modifications of the curriculum, however, this bias toward inclusion is not absolute. Faculty should resist additions that "cannot be justified academically" and should be open to deletions if they are convinced that "what is deleted was not academically justifiable" (Principle 6). Open discussions of curriculum in noncoercive contexts are themselves an important aspect of academic freedom.

\section{CONCLUSION}

Restrictions on education about sexual orientation are pervasive throughout elementary and secondary education and all too common in higher education as well. Given this state of affairs it is understandable that in those circumstances where sexual minorities, and those sympathetic to sexual minority viewpoints, find themselves in power they will be tempted to compensate by indoctrinating students in their own views. A better approach, I have suggested, regardless of who has the power to devise and administer the curriculum, is to educate students in accord with principles of academic freedom such as those proposed by AFCON.

The proposed principles permit advocacy, rather than requiring neutrality, but do not permit indoctrination. That is, instructors may express and justify their own ideas relevant to the curriculum and try to convince students to adopt those ideas and/or to abandon alternatives, but must not coerce or require belief, censor or punish students who remain unconvinced, or restrict access to alternative views. Adherence to these principles will, I suggest, permit effective education about matters of sexual orientation that is fully consistent with the rights of all involved.

\section{REFERENCES}

American Association of University Professors (2001). 1940 Statement of Principles on Academic Freedom and Tenure, with 1970 interpretive comments. In Policy documents and reports (9th ed., pp. 3-10). Washington, DC: AAUP.

Hazelwood School District v. Kuhlmeier (1988). 484 U.S. 260

Kors, A. C., \& Silverglate, H. A. (1999). The shadow university: The betrayal of liberty on America's campuses. New York: HarperPerennial.

Moshman, D. (1998). Cognitive development beyond childhood. In W. Damon (Series Ed.), D. Kuhn \& R. Siegler (Vol. Eds.), Handbook of child psychology: Vol. 2. Cognition, perception, and language (5th ed.) (pp. 947-978). New York: Wiley.

Moshman, D. (1999). Adolescent psychological development: Rationality, morality, and identity. Mahwah, NJ: Erlbaum.

O'Neil, R. M. (1997). Free speech in the college community. Bloomington: Indiana University Press. 


\section{APPENDIX}

Principles of Academic Freedom adopted by the Academic Freedom Coalition of Nebraska (AFCON) on September 11, 1999

1. Nature and Purpose of Academic Freedom. Academic freedom refers to intellectual freedom in educational and research contexts, including freedoms of belief, expression, discussion, and inquiry. A commitment to intellectual freedom respects the rights of students and teachers and creates an educational context that promotes learning, development, and original research.

2. Freedom of Belief. All individuals, including students and teachers, have a right to believe whatever they believe and to maintain or change their beliefs as they deem appropriate. Educational institutions may present alternative views but may not require belief in those views. Students may be evaluated and graded with regard to their understanding of curricular material but not on the basis of their agreement with particular viewpoints.

3. Freedom of Expression. All individuals have a right to express their views privately and publicly and to discuss them with others. In academic contexts, students and teachers have a right to express their views on any matter relevant to the curriculum even if those views are deemed to be false, absurd, offensive, or otherwise objectionable. Some restrictions on expression are justifiable in cases where individuals are speaking in an official capacity on behalf of the institution.

4. Freedom of Inquiry. Educational institutions should encourage individuals to pursue their own interests and ideas and should promote access to relevant sources of information. Inquiry should not be suppressed by restricting access to controversial topics or viewpoints or by hindering the formulation of conclusions that may be deemed objectionable.

5. Formulation of Curriculum. Curriculum should be determined by teachers and other professionals on the basis of academic considerations. It is a responsibility of administrators and school boards to support justifiable curricular decisions and to educate their constituencies about the educational importance of an inclusive curriculum and the critical role of respect for academic freedom.

6. Challenges to the Curriculum. Suggested modifications of the curriculum should not be accepted merely to resolve a complaint, but neither should such suggestions be automatically rejected as illegitimate. In general, changes that expand the curriculum are more likely to be appropriate than changes that contract or restrict it. On the other hand, additions may be illegitimate if what is added cannot be justified academically, and deletions may be appropriate if what is deleted was not academically justifiable.

7. Parental Rights. Parents have a right to discuss their views with their own children and to communicate with the school if they have suggestions or concerns about what they perceive the school to be teaching. Schools should accept the responsibility of explaining and justifying their curricula. In general, parents have the authority to direct their own minor children's education, subject to the responsibility of the school to provide an adequate education and to respect the rights of the student.

8. Equal Opportunity. Students and teachers have a right to academic freedom regardless of individual, biological, cultural, religious, theoretical, ideological, political or other characteristics, backgrounds, or viewpoints.

9. Privacy. In seeking information about potential or current employees and students, academic institutions should avoid making official inquiries that target personal expressive activities or that are so broadly or vaguely defined as to chill intellectual freedom. With regard to academic assignments, students may be encouraged to speak or write about their lives, and may choose to do so, but may not be required to reveal personal information that they wish to keep private.

10. Due Process. Academic institutions should ensure that their judicial and quasi-judicial procedures provide sufficient due process to protect intellectual freedom. 